\title{
E
}

Entrepreneurial Business and Economics Review

2014, Vol. 2, No. 1

\section{Business Restart in Visegrad Countries}

\author{
Marian Holienka, Anna Pilková, Michal Munk ${ }^{1}$
}

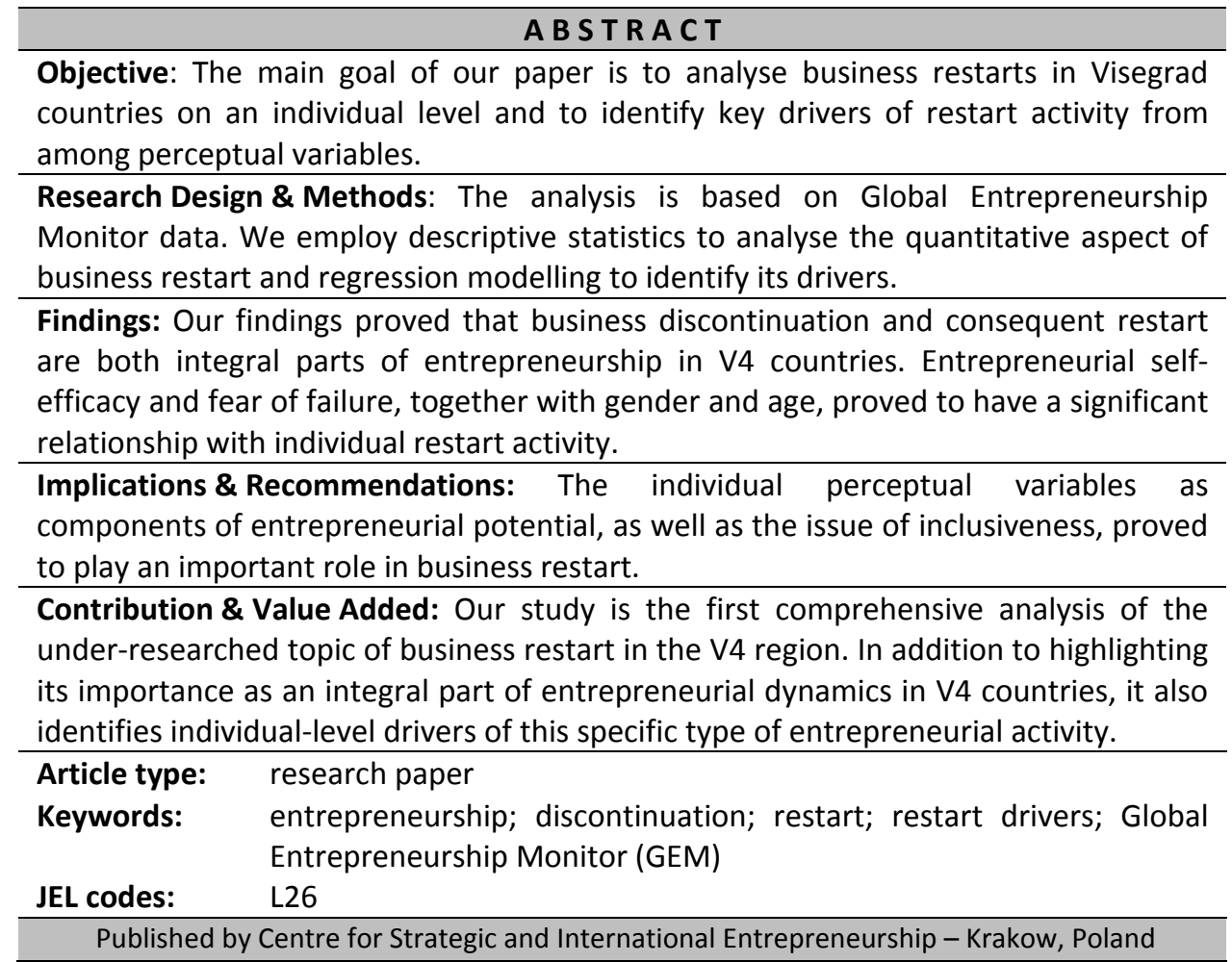

\section{Suggested citation:}

Holienka, M., Pilková, A. \& Munk, M. (2014). Business Restart in Visegrad Countries. Entrepreneurial Business and Economics Review, 2(1), 37-48.

\footnotetext{
${ }^{1}$ The contribution of co-authors is equal and can be expressed as $33.3 \%$ each of the authors. M. Holienka and A. Pilkova prepared the literature review and results and discussion, while M. Munk prepared the statistical calculations.
} 


\section{INTRODUCTION}

Entrepreneurship is viewed as an important driver of economic development and one of the keys to solve some of the most pressing current problems, such as unemployment (including youth unemployment) and economic growth. Most of the attention in understanding and promoting entrepreneurship has been paid to so-called first movers or novice entrepreneurs, i.e. individuals who enter the entrepreneurial path for the first time. However, a considerable number of entrepreneurs sooner or later come across the situation where they exit the entrepreneurial process, either after success or following a failure. These individuals stand at an important crossroads along their career path, deciding between abstaining from entrepreneurship or re-entering the entrepreneurship process again and restarting their business activity. If they decide to completely restart from new, they are able to capitalize upon previous experience and utilize the learning gained in their previous entrepreneurial activity. Restarted entrepreneurs therefore deserve at least equal attention as their novice counterparts. Better understanding of the drivers behind the decision to restart entrepreneurial activity after discontinuance can help to design support mechanisms which encourage individuals to restart, thus preserving the stock of existing entrepreneurs and developing the overall entrepreneurial potential of the economy. Therefore, when trying to understand and promote entrepreneurship in general, the focus should not only be on promoting new entrepreneurs, but also on preserving the stock of current ones, even after they exit the process. Therefore, the main research question of our article is to find out the level of business restart in V4 countries (how many discontinued entrepreneurs restart their business activities), and what are the main drivers (from among perceptual variables) of their restart activities.

The attention devoted by entrepreneurship research to the issue of business restart is rather scarce, especially compared to the scope of research focused on novice entrepreneurs or drivers of entering the entrepreneurship process in general. However, the recent studies by Hessels et al. (2011) or Simmons et al. (2014) together with our study on business restart in Slovakia (Pilkova et al., 2013a) brought interesting insights to this topic as well as identified several implications. One of the latter, in our opinion, is the investigation into the quantitative aspects and restart drivers in the context of Czech Republic, Hungary, Poland and Slovak Republic, a regional group of Visegrad or V4 countries. These countries face a similar historic background as well as similar challenges in the field of entrepreneurship and overall economic development. The analysis of the business restart phenomenon in V4 is, however, still missing, as at this moment.

Our investigation of business restart in V4 countries is focused on identifying the restart rate (i.e. the percentage of restarted entrepreneurs on discontinued entrepreneurs), and mainly on identifying the individual-level drivers from among perceptions towards entrepreneurship that foster business restart among discontinued entrepreneurs. These restarted individuals play at least as important role in the country's entrepreneurial potential as first-mover entrepreneurs do, therefore they deserve the same level of attention from the communities of both researchers and policy makers. To identify the key drivers of business restart in V4 countries we studied both entrepreneurial potential and demographic aspects. As far as entrepreneurial potential is 
concerned, we focused on its three basic aspects: business opportunity recognition, social attitudes towards entrepreneurship (in our case explained through the perceived social status of successful entrepreneurs) and self-assessment regarding entrepreneurship (studied through self-efficacy and fear of failure). As for demographics, we have studied two basic characteristics, gender and age.

\section{LITERATURE REVIEW}

Entrepreneurship is generally understood as a process (Bygrave, 1989; Cardon et al., 2005; Reynolds, 1992) irrespective of the sequence of particular phases or their length. This process ends with discontinuation of the entrepreneurial activity, also referred to as entrepreneurial exit (DeTienne, 2010; Wennberg et al., 2010); at which moment the individuals end their involvement in entrepreneurship. There are several possible reasons for discontinuation, ranging from success through neutral reasons to entrepreneurial failure. After discontinuation the individual has two basic options - $s / h e$ can abstain from entrepreneurship (either thinking of starting again or not even planning to do so) or s/he can actually start new entrepreneurial activity again; in this case s/he re-enters the entrepreneurship process from the beginning. We refer to this situation as "business restart" and we call the entrepreneur who restarts his/her activity after business discontinuation a "restarted entrepreneur". Business restart is by nature a specific type of entrepreneurial activity. Therefore when trying to understand the restart drivers, the attention should be focused on drivers of individual involvement in entrepreneurial activity in general, while carefully considering the specific nature of business restart. Among the most frequently identified determinants of individual entrepreneurial activity are individual perceptions of entrepreneurship, such as entrepreneurial self-efficacy, opportunities perception or fear of failure, as well as individual perceptions of societal attitudes towards entrepreneurship, such as perceived social status of successful entrepreneurs (Arenius \& Minniti, 2005; Bosma, 2013; Koellinger et al., 2007). All these components together create the so called entrepreneurial potential of the economy (Pilkova et al., 2012). Even though the relationship between entrepreneurial potential and actual entrepreneurial activity is not straightforward but rather complex, its components, including perceptions of one's own skills, fear of failure, opportunities to start up as well as of social attitudes towards entrepreneurship, were each established as important drivers of entrepreneurial activity in both theory development as well as empirical research.

Perceived self-efficacy represents one's judgment of one's ability to execute an action and to produce designated levels of performance (Bandura, 1994). Therefore it has been established as a reliable predictor of a wide range of goal-directed behaviours, including also entrepreneurship. Self-efficacy is strongly related to perceived behavioural control and ability (concerning the ease with which the particular behaviour is controlled), that together with attitude toward behaviour and subjective norm affect the intention, which in turn affects the actual behaviour of an individual (Ajzen, 1991). In this case, the context-specific entrepreneurial self-efficacy represents the belief and selfconfidence of an individual in having the necessary skills and abilities to start and run a business. The empirical evidence has proved high levels of entrepreneurial self-efficacy 
have a positive relationship with individual entrepreneurial activity (Arenius \& Minniti, 2005; Lukes et al., 2013; Wong \& Lee, 2005).

Perception of opportunities relates to subjective alertness of an individual to good opportunities for starting up and running an enterprise. The alertness to unexploited opportunities, as argued by Kirzner (1979), is a key perceptual characteristic of entrepreneurial behaviour and a necessary condition for entrepreneurial action. Some empirical research provided evidence that those who perceive opportunities are more likely to get involved in entrepreneurship than those who do not (Arenius \& Minniti, 2005; Koellinger et al., 2007).

Fear of failure represents a subjective perception regarding the risk of failure and its possible consequences. Perceived (rather than objective) fear of failure is therefore an important component of risk related to entering the entrepreneurial process. Because the majority of individuals are supposed to be risk averse by nature, increased fear of failure is expected to act as an inhibitor of entrepreneurial action (Arenius \& Minniti, 2005). Empirical research has provided certain evidence supporting these expectations considering entrepreneurial activity in general (Arenius \& Minniti, 2005; Wagner, 2007) as well as concerning business restart in particular (Hessels et al., 2011; Pilkova et al., 2013a; Wagner, 2002). On the other hand, it has also revealed limitations of the risk aversion effect related to previous employment status (Caliendo et al., 2009). Additionally, findings by Simmons et al. (2014) suggest that the micro-macro level effect of stigmatization of failure (potentially leading to a subsequent fear of failure) in failed entrepreneurs and their restart is not unambiguous and depends on institutional context as well as on individual cognitive processes.

Perceptions of social attitudes towards entrepreneurship are subjective perceptions of social norms, values, beliefs and assumptions that are socially carried by individuals and related to their behaviour. In this case we speak about informal institutions (North, 1990), or more specifically about normative institutional pillar (Scott, 1995) in relation to entrepreneurship. In the entrepreneurial context they shape the entrepreneurial activity of individuals (a context-specific type of human behaviour and interaction) by forming social attitudes towards entrepreneurship. One of these is also the status of a successful entrepreneur in a particular society. If an individual believes successful entrepreneurs enjoy a high social status, s/he is supposed to be more likely to find entrepreneurial activity desirable. $\mathrm{S} / \mathrm{h}$ e would perceive that his/her individual action will conform to norms and values within society, and thus s/he will, by joining the entrepreneurial path, achieve legitimacy in this society (Lonsburry \& Glynn, 2001).

In addition to the above-mentioned perceptual characteristics, demographic characteristics that are intrinsic by their nature (mainly age and gender) have also been identified as determinants of entrepreneurship (Langowitz \& Minniti, 2007; Lukes et al., 2013). Gender studies suggest that entrepreneurial activity of men and women may be affected by differences that can be attributed to certain gender-specific characteristics (Langowitz \& Minniti, 2007). The role of age as a crucial characteristic in the decision making process at the entry to entrepreneurial activity is based on the opportunity cost of time. Time is treated as a scarce resource whose availability is decreasing with age, in contrast to the decrease in the present value of a stream of potential (however uncertain) future payments possibly obtained by starting up an entrepreneurial activity. 
Put simply, with increasing age the opportunity costs of choosing an entrepreneurial path generally increase (Lévesque \& Minniti, 2006). Therefore, both these basic demographic characteristics might play important roles in determining entrepreneurship process entry by an individual. Where business restart is especially concerned, previous findings suggest that age plays an important role in determining business restart (Stam et al., 2008; Wagner, 2002), and some studies also proved gender to have significant influence (Hessels et al., 2011; Pilkova et al., 2013a), with males restarting discontinued businesses more often than their female counterparts.

\section{MATERIAL AND METHODS}

In this section of our paper we present and describe the data and variables used in our analysis, its main goals, as well as the hypotheses and testing methods employed.

\section{Data and Variables}

Our analysis is based on Global Entrepreneurship Monitor (GEM) data. GEM is the largest academic study in the world focused on entrepreneurial attitudes, activities and aspirations. Every year GEM collects in each participating country using a standardized survey administered to a representative sample of adults (18 to 64 years old). In our analysis of business restart in V4 countries we created a pooled sample using GEM individual level data from years 2011 and 2012 for V4 countries, leading to a total primary sample of 14,010 individuals (2,005 for Czech Republic that participated in 2011 only, 4,002 for Hungary, 4,003 for Poland and 4,000 for Slovakia).

Firstly, using the survey data we identified individuals who experienced business discontinuation, i.e. respondents who had in the past 12 months sold, shut down, discontinued or quit a business they owned and managed. Our sample included in total 451 of such individuals (due to method requirements we have excluded individuals with missing values for independent variables). Secondly, we identified early-stage entrepreneurs as individuals in the process of actively starting a business or running a new business less than 3.5 years old. Thirdly, by overlapping the aforementioned categories we were able to identify restarted entrepreneurs as those individuals who restarted their individual entrepreneurial activity after business discontinuation. This group represented the main sample for our analysis of business restart drivers.

Since our analysis is aimed at investigating the drivers of restart activity, we employed the following independent variables representing the particular underlying phenomena from among perceptions towards entrepreneurship and demographic characteristics: 1) self-efficacy: respondents were asked whether they believe they had the knowledge, skill and experience required to start a new business (yes=1, no=0), 2) fear of failure: respondents were asked whether fear of failure would prevent them from starting a business (yes $=1$, no= $=0$ ), 3) opportunities perception: respondents were asked whether in the next six months there would be good opportunities for starting a business in the area where they live (yes $=1$, no=0), 4) perceived high status of successful entrepreneurs: respondents were asked whether in their country those successful at starting a new business have a high level of status and respect (yes $=1$, no=0), 5) age: respondents provided their age, 6 ) gender: respondents provided their gender (male=1, female=2). Besides the above mentioned independent variables we also controlled for 
the effect of education (variable coding was based on UN harmonized educational attainment) and country affiliation.

\section{Hypotheses}

In addition to unveiling the quantitative aspects of business restart in Visegrad countries (such as the restart rate or share of restarted entrepreneurs on early-stage entrepreneurs) we investigated the potential drivers of individual restart activity. Building on the above-reviewed theory, empirical research on entrepreneurial activity determinants in general and determinants of business restart, as well as on our previous work in this field, we propose the following hypotheses on business restart drivers in Visegrad countries:

H1: Entrepreneurial self-efficacy positively affects restart activity, i.e. entrepreneurial self-efficacy is a significant driver of business restart in V4 countries.

$\mathrm{H} 2$ : Alertness to entrepreneurial opportunities positively affects restart activity, i.e. alertness to opportunities is a significant driver of business restart in V4 countries.

H3: Fear of failure negatively affects restart activity, i.e. fear of failure is a significant driver of business restart in V4 countries.

H4: Belief in high social status of successful entrepreneurs positively affects restart activity, i.e. belief in high social status of successful entrepreneurs is a significant driver of business restart in V4 countries.

H5: Business restart is mainly dominated by men, i.e. gender is a significant driver of business restart in V4 countries.

H6: Business restart activity declines with the age of discontinued entrepreneurs, i.e. age is a significant driver of business restart in V4 countries.

\section{Methods}

To investigate the quantitative aspect of business restart in Visegrad countries we analyzed the situation in each country for each year individually using descriptive statistics. We calculated frequencies for discontinued entrepreneurs within the adult population, restarted entrepreneurs within discontinued entrepreneurs, and restarted entrepreneurs within early-stage entrepreneurs. To search for potential business restart drivers a binominal logistic regression modelling was applied on a pooled sample of discontinued entrepreneurs from the analysed V4 countries. Binominal logistic regression estimates the probability of an event happening. In our case this event was restarting an entrepreneurial activity after discontinuation. To estimate the parameters of individual level data we used Statistica Generalized Linear/Nonlinear Models. Requirements of the method (no missing values for any of the independent variables) implied the exclusion of certain cases, resulting in a final sample of 451 individuals. The significance of parameters was tested using Wald statistics. Maximum likelihood estimations were used to calculate the logit coefficients denoting changes in the log odds of the dependent variable. Correlations between independent variables were tested and proved not to be problematic. Residual analysis was used to identify cases with the greatest contribution to model inaccuracy. After their elimination the analysis was repeated, resulting in the final regression model. The goodness of fit of the model was assessed using the Pearson's Chi-square test and log-likelihood function. 


\section{RESULTS AND DISCUSSION}

This section of our paper presents and discusses the results of our analysis. Firstly, we describe the issue of business discontinuance and restart in V4 countries. Secondly, we present results about the individual characteristics related to business restart and to its potential drivers.

\section{Business Restart in V4 Countries}

The business discontinuance rate, represented as the percentage of the adult population that personally experienced business discontinuance in last 12 months, varied among V4 countries from 2.7\% (Czech Republic) to 7.0\% (Slovakia) in 2011 and from 3.8\% (Hungary) to $4.7 \%$ (Slovakia) in 2012 (Table 1). In both years Slovakia showed the highest figures in this indicator. The results also show that restart rate in V4 countries was ranging from 6.9\% (Hungary, 2011) to as much as 29.3\% (Poland, 2012). From the opposite perspective, looking at the share of restarted entrepreneurs among all early-stage entrepreneurs (those individuals starting new enterprises less than 42 months old) revealed that from 2.5\% (Hungary, 2011) to as much as $13.9 \%$ (Slovakia, 2011) of earlystage entrepreneurs were actually restarting their business after exiting another one.

Table 1. Business discontinuation and business restart in V4 countries in 2011 and 2012

\begin{tabular}{|c|r|r|r|r|r|r|}
\hline \multirow{2}{*}{ Country } & \multicolumn{2}{|c|}{$\begin{array}{c}\text { Discontinued } \\
\text { entrepreneurs } \\
\text { (\% of adult population) }\end{array}$} & \multicolumn{2}{|c|}{$\begin{array}{c}\text { Business restart } \\
\text { (\% of discontinued } \\
\text { entrepreneurs) }\end{array}$} & \multicolumn{2}{|c|}{$\begin{array}{c}\text { Restarted entrepreneurs } \\
\text { (\% of early-stage } \\
\text { entrepreneurs) }\end{array}$} \\
\cline { 2 - 7 } & $\mathbf{2 0 1 1}$ & $\mathbf{2 0 1 2}$ & $\mathbf{2 0 1 1}$ & $\mathbf{2 0 1 2}$ & $\mathbf{2 0 1 1}$ & $\mathbf{2 0 1 2}$ \\
\hline Czech Republic & 2.7 & NA & 14.9 & NA & 5.3 & NA \\
\hline Hungary & 2.3 & 3.8 & 6.9 & 24.1 & 2.5 & 9.9 \\
\hline Poland & 4.2 & 3.9 & 10.4 & 29.3 & 4.8 & 12.2 \\
\hline Slovakia & 7.0 & 4.7 & 28.3 & 22.3 & 13.9 & 10.2 \\
\hline
\end{tabular}

Source: own calculations based on GEM 2011 and 2012 data.

The above mentioned findings suggest that in all V4 countries a considerable part of the adult population exited the entrepreneurship process, representing the decline of those countries' actual entrepreneurial potential in terms of quantity. On the other hand, despite the observed differences in figures for particular countries, business restart proved to be an integral part of the entrepreneurship process in V4 countries as well. 2012 restart rates in particular showed a relatively consistent pattern among the three analysed countries (the Czech Republic was not analysed in 2012 due to missing data), suggesting that approximately every fourth entrepreneur who experienced business discontinuation restarted his individual entrepreneurial activity. In addition, from the opposite perspective, analysing the number of restarted individuals out of all early-stage entrepreneurs further proved the importance of the business restart phenomenon, since it underlined that a considerable share of early stage entrepreneurial activity can be attributed to business restart. Similarly to the previous perspective, also in the last indicator the 2012 figures were more homogeneous than in previous year. They suggest a common pattern existed among the analysed countries showing that approximately every tenth early-stage entrepreneur was a restarted 
entrepreneur, i.e. an individual who experienced business discontinuation in last year and restarts his individual entrepreneurial activity again.

\section{Business Restart Drivers in V4 Countries}

The binomial logistic regression conducted in order to identify the potential drivers in relation to business restart suggested that four out of six analysed variables were significant (Table 2). Both demographic characteristics (age and gender) together with entrepreneurial self-efficacy and fear of failure proved their significance in relation to business restart. Therefore we can consider our hypotheses $\mathrm{H} 1, \mathrm{H} 3, \mathrm{H} 5$ and $\mathrm{H} 6$ to be supported. On the other hand, since our analysis showed no significance of alertness to opportunities and belief of high social status of successful entrepreneurs, we found no support for our hypotheses $\mathrm{H} 2$ and $\mathrm{H} 4$. As far as control variables are concerned, their effect was also found not to be significant, suggesting that our results are not influenced by the year of data collection or by country affiliation.

Table 2. Business restart drivers in V4 countries (logistic regression results)

\begin{tabular}{|l|r|r|r|r|}
\hline \multicolumn{1}{|c|}{ Drivers } & \multicolumn{1}{c|}{ Coeff. } & \multicolumn{1}{c|}{ Std. error } & \multicolumn{1}{c|}{ Wald } & \multicolumn{1}{c|}{ p } \\
\hline Gender (1=male, 2=female) & -1.20057 & 0.29703 & 16.33725 & 0.000053 \\
\hline Age & -0.03760 & 0.01093 & 11.83166 & 0.000582 \\
\hline Self-efficacy (1=yes, 0=no) & 3.26245 & 1.02498 & 10.13118 & 0.001458 \\
\hline Fear of failure (1=yes, 0=no) & -1.11268 & 0.28997 & 14.72394 & 0.000124 \\
\hline Df & & 439 \\
\hline LR stat. & & 381.772 \\
\hline Pearson Chi-sq. stat. & 0.869641 \\
\hline LR stat./df & 0.871706 \\
\hline Pearson Chi-sq. stat/df & -190.886 \\
\hline Log-likelihood
\end{tabular}

Source: own calculations.

According to our findings regarding entrepreneurial potential components, entrepreneurial self-efficacy and fear of failure are significantly related to business restart in V4 countries. However, alertness to opportunities and belief in the high social status of successful entrepreneurs showed no significance. On the other hand, both demographic characteristics included in our analysis, i.e. age and gender, proved significant in relation to business restart.

Our findings are in line with the theory-based expectations and the results of previous empirical research suggesting that (often subjective) perceptions towards entrepreneurship play significant roles in affecting entrepreneurial propensity. Selfefficacy was identified as having the strongest relationship with business restart from the variables included in our analysis, with the belief in having the knowledge, skill and experience required to start a new business increasing the chance of restart by 3.26 times. On the other hand, having a fear of failure that would prevent an individual from starting a new business showed a negative relationship to business restart, decreasing its probability by 1.11 times. This finding corresponds with the previous findings in this field (Hessels et al., 2011; Pilkova et al., 2013a; Wagner, 2002), supporting the robustness of considering the fear of failure as an important driver of business restart. However, we did not expect that the relationship of opportunities perception and the perception of 
the high social status of successful entrepreneurs showed no significant relationship to restarting a business after entrepreneurial exit.

As for demographic characteristics, our findings suggest that with increasing age the probability of restart after business discontinuation decreases. This corresponds not only with the general pattern of decreased probability of entrepreneurial entry with increasing age, but also with the findings of other studies on business restart (Pilkova et al., 2013a; Stam et al., 2008; Wagner, 2002). Here we might conclude that generally occurring descending activity with rising age due to increasing opportunity costs of entrepreneurship applies also to business restart as a specific type of entrepreneurial activity. Similarly, gender-specific factors affecting entrepreneurial activity in general seem to influence the business restart in V4 countries as well, because as our results suggest, male exited entrepreneurs show a higher restart propensity than their female counterparts. These findings are in line with previous research in business restart (Hessels et al., 2011; Pilkova et al., 2013a) as well as in line with underrepresented inclusion of women (compared to population distribution) in early-stage entrepreneurial activity that is characteristic throughout all V4 countries (Pilkova et al., 2013b). This pattern might be explained by differences in self-assessment between men and women, since women in general show a higher fear of failure and lower self-confidence regarding entrepreneurship (Pilkova et al., 2012; Weclawska et al., 2013).

The potential implications of our research include an improved understanding of business restart in Visegrad countries, not only limited to a quantitative view, but also going deeper in search of perceptual variables and entrepreneurial potential influence. As far as implications for further research are concerned, we propose that further attention should be paid to comparing the business restart patterns with overall (nonrestart) activity to explore other potential universal as well as restart-specific drivers, and challenge the robustness of existing findings. Also, a relationship between business restart and entrepreneurial context (represented by business environment) should be established. Both these streams would however require considerable samples and timeseries data. At this place, longitudinal studies with panel samples would be beneficial in this field of study. Further research should also focus on multi-level analysis, considering the simultaneous effects of both micro- and macro-level potential drivers of business restart.

Regarding implications for policy makers, the strong positive relationship between self-efficacy and business restart implies the need for supporting and educational programs that would develop the knowledge and skills of future and existing entrepreneurs, not only by increasing the hard skills themselves, but also by fostering self-confidence in their application. Also in this area entrepreneurial role models could play an important role as important sources of social capital, transferring knowledge and experience, as well as important enhancers of entrepreneurial self-efficacy (Holienka et al., 2013). Secondly, policy makers should also pay attention to factors influencing the level of fear of failure among entrepreneurs as well as among the overall population in general. In this field both cultural as well as practical aspects play roles. Therefore moderating the fear of failure should include influencing social attitudes and norms (through e.g. education or success stories) as well as an effort to improve the legislative and bureaucratic aspects of honest bankruptcy and business restart. Finally, the uneven 
inclusion of genders and age groups in business restart should be addressed by eliminating both individual-level as well as environmental barriers of inclusiveness, to reach the situation where business restart after discontinuation would be equally accessible to everyone willing to restart, irrespective of age or gender. Therefore specific support programs aimed at groups lacking in restart, together with creating favourable conditions to restart in general should be priorities for policy makers. Underrepresented groups in business restart are usually also underrepresented in entrepreneurship in general. By supporting restart among these groups policy makers could therefore contribute not only to their inclusion in restarting after discontinuation, but also to protection of the overall stock of entrepreneurs from these groups and therefore to improving the issue of inclusiveness in general.

The main limitation of our approach is due to the nature of GEM data. Since they provide a static view at the moment of data collection, we are not able to uncover the timeline of key events (business discontinuance, involvement in early-stage entrepreneurial activity) and avoid their overlapping in certain cases. Also, the GEM variables do not allow for an unambiguous distinction between success and failure as reasons for entrepreneurial exit. However, harmonized methodology, scope and representative characteristics of the sample and focus on individuals (rather than corporate entities) make GEM the best available data source to understand the issue of business restart in Visegrad countries. To improve the robustness of the findings, a repeated analysis should be done in the future with pooled data and controlled influence of year and country affiliation.

\section{CONCLUSIONS}

Our analysis of business restart in V4 countries proved that this phenomenon is an integral part of the entrepreneurship process and its dynamics in the V4 region. In 2012, approximately every fourth discontinued entrepreneur restarted his/her individual entrepreneurial activity, representing around $10 \%$ of total early-stage entrepreneurial activity. Our further investigation on drivers of this restart suggested that individual perceptual characteristics (in particular entrepreneurial self-efficacy and fear of failure) together with demographic characteristics (age and gender) are important drivers in relation to business restart in V4 countries. Therefore, of the entrepreneurial potential components, only self-assessment regarding entrepreneurship proved important in influencing business restart by discontinued entrepreneurs, while the other two components (i.e. business opportunity recognition and social attitudes towards entrepreneurship) showed no significance in our analysis. The findings of our study represent the first systematic view on the business restart phenomenon in the V4 region, contributing to the understanding of entrepreneurship and entrepreneurial propensity in our region's context.

\section{REFERENCES}

Ajzen, I. (1991). The theory of planned behavior. Organizational Behavior and Human Decision Processes, 50(2), 179-211. 
Arenius, P., \& Minniti, M. (2005). Perceptual variables and nascent entrepreneurship. Small Business Economics, 24(3), 233-247.

Bandura, A. (1994). Self-efficacy. In Encyclopedia of human behavior. (Vol. 4, pp. 71-81). New York, NY: Academic Press.

Bosma, N. (2013). The Global Entrepreneurship Monitor (GEM) and its impact on entrepreneurship research. Foundations and Trends in Entrepreneurship, 9(2), 143-248.

Bygrave, B. (1989). The entrepreneurship paradigm (II): chaos and catastrophes among quantum jumps?. Entrepreneurship Theory and Practice, 14(2), 7-30.

Caliendo, M., Fossen, F. M., \& Kritikos, A. S. (2009). Risk attitudes of nascent entrepreneurs - new evidence from an experimentally validated survey. Small Business Economics, 32(2), 153167.

Cardon, M.S., Zietsma, Ch., Saparito, P., Matherne, B. P., \& Davis, C. (2005). A tale of passion: new insights into entrepreneurship from a parenthood metaphor. Journal of Business Venturing, 20(1), 23-45.

DeTienne, D. R. (2010). Entrepreneurial exit as a critical component of the entrepreneurial process: theoretical development. Journal of Business Venturing, 25(2), 203-215.

Hessels, J., Grilo, I., Thurik, R., \& Van der Zwan, P. (2011). Entrepreneurial exit and entrepreneurial engagement. Journal of Evolutionary Economy, 21(3), 447-471.

Holienka, M., Mrva, M., \& Marcin, P. (2013). Role of family entrepreneurial role models in determining students' preferences towards entrepreneurship. In L. Gomez Chova (Ed.), ICERI2013 Proceedings (pp. 3722-3730). IATED.

Kirzner, I. M. (1979). Perception, Opportunity and Profit. Chicago, IL: University of Chicago Press.

Koellinger, P., Minniti, M., \& Schade, Ch. (2007). "I think I can, I think I can": Overconfidence and Entrepreneurial Behavior. Journal of Economic Psychology, 28(8), 502-527.

Langowitz, N., \& Minniti, M. (2007). The entrepreneurial propensity of women. Entrepreneurship Theory and Practice, 31(3), 341-364.

Lévesque, M., \& Minniti, M. (2006). The effect of aging on entrepreneurial behavior. Journal of Business Venturing, 21(2), 177-194.

Lonsburry, M., \& Glynn, M. A. (2001). Cultural entrepreneurship: stories, legitimacy, and the acquisition of resources. Strategic Management Journal, 22(6-7), 545-564.

Lukes, M., Zouhar, J., Jakl, M., \& Ocko, P. (2013). Faktory ovlivnujici vstup do podnikani: Zacinajici podnikatele v Ceske republice. Politická ekonomie, 61(2), 229-247.

North, D. C. (1990). Institutions, Institutional Change and Economic Performance. Cambridge: Cambridge University Press.

Pilkova, A., Kovacicova, Z., Holienka, M., \& Rehak, J. (2012). Podnikanie na Slovensku: vysoka aktivita, nizke rozvojove aspiracie. Bratislava: Comenius University in Bratislava.

Pilkova, A., Holienka, M., \& Munk, M. (2013a). Key business restart drivers in Slovakia. Acta Universitatis Agriculturae et Silviculturae Mendelianae Brunensis, 61(7), 2617-2622.

Pilkova, A., Holienka, M., Kovacicova, Z., Rehak, J., \& Pesout, I. (2013b). Podnikanie na Slovensku: nadpriemerna podnikatelska aktivita v podpriemernom podnikatelskom prostredi. Bratislava: Comenius University in Bratislava.

Reynolds, P. (1992). New firm gestation: conception, birth and implications for research. Journal of Business Venturing, 7(5), 405-417.

Scott, W. R. (1995). Institutions and Organizations. Thousand Oaks, CA: Sage Publications. 
Simmons, S. A., Wiklund, J., \& Levie, J. (2013). Stigma and business failure: implications for entrepreneurs' career choices. Small Business Economy, 42(3), 485-505.

Stam, E., Audretsch, D., \& Meijaard, J. (2008). Renascent entrepreneurship. Journal of Evolutionary Economy, 18(3-4), 493-507.

Wagner, J. (2002). Taking a Second Chance: Entrepreneurial Restarters in Germany. IZA Discussion Paper No. 417. Bonn: Institute for the Study of Labor.

Wagner, J. (2007). What a difference a $Y$ makes - female and male nascent entrepreneurs in Germany. Small Business Economics, 28(1), 1-21.

Węcławska, D., Zbierowski, P., Tarnawa, A., \& Bratnicki, M. (2013). Global Entrepreneurship Monitor report - Poland 2012. Warsaw: Polish Agency of Enterprise Development.

Wennberg, K., Wiklund, J., DeTienne, D. R., \& Cardon, M. S. (2010). Reconceptualizing entrepreneurial exit: divergent exit routes and their drivers. Journal of Business Venturing, 25(4), 361-375.

Wong, P. K., \& Lee, L. (2005). Antecedents for entrepreneurial propensity in Singapore. NUS Entrepreneurship Centre working papers No. WP2005-12. Singapore: National University of Singapore.

\section{Authors}

\section{Marian Holienka}

Post doc teaching assistant and researcher at Comenius University in Bratislava (Slovakia), Faculty of Management, Department of Strategy and Entrepreneurship. PhD in Business Administration by Comenius University in Bratislava (Slovakia); Degree in Management with major in Strategic Management by Comenius University in Bratislava (Slovakia).

\section{Anna Pilková}

Associate Professor and Head of Department at Comenius University in Bratislava (Slovakia), Faculty of Management, Department of Strategy and Entrepreneurship. PhD in Economics and Management of Industries - Organization and Management of Industrial Enterprises by University of Economics in Bratislava (Slovakia); MBA by Rochester Institute of Technology (USA); Degree in Economics and Management of Industries by University of Economics in Bratislava (Slovakia).

\section{Michal Munk}

Associate Professor at Constantine the Philosopher University in Nitra (Slovakia), Faculty of Natural Sciences, Department of Informatics. PhD in Mathematics by Constantine the Philosopher University in Nitra (Slovakia); Degree in Mathematics and Computer Science by Constantine the Philosopher University in Nitra (Slovakia).

\section{Correspondence to:}

Mgr. Marian Holienka, PhD

Comenius University in Bratislava

Faculty of Management,

Odbojarov, 10, 82005 Bratislava, Slovakia

marian.holienka@fm.uniba.sk 